"It was perhaps naive and overly optimistic to believe that regime change was the answer to a problem that has much deeper structural roots."

\title{
The Tangled Politics of Postwar Justice in Sri Lanka
}

\author{
JONATHAN GOODHAND AND OLIVER WALTON
}

$\mathrm{W}$ hen does a "postwar" period begin and when does it end? The victory of the Sri Lankan military over the Tamil militant group the Liberation Tigers of Tamil Eelam (LTTE) in May 2009 was widely celebrated in the Sinhalese-majority south of the country, where it was hailed as the end of a civil war that had lasted for more than 25 years. Although the war ended with a crushing defeat for the LTTE (and with thousands of civilians killed in the final government offensive), in the years that followed the government appeared desperate to maintain the sense of a country permanently at war, expanding the role of the military in many areas of public life and consolidating its occupation of the north and east.

For this reason, many felt that the war did not properly end until Maithripala Sirisena's unexpected defeat of the incumbent Mahinda Rajapaksa in the January 2015 presidential election, which was seen as either the beginning of, or a critical turning point in, Sri Lanka's postwar transition. This victory for a coalition of Sri Lanka's two largest parties, the United National Party (UNP) and the Sri Lanka Freedom Party (SLFP), appeared to open up a historic opportunity to bring about a lasting and just peace, reversing the drift toward "soft authoritarianism" under Rajapaksa and dismantling the victor's peace that his regime had imposed.

Parliamentary elections in August 2015 confirmed the mandate of Sirisena's new yahapalana$y a$, or "good governance," coalition-a capacious term that had broad-based appeal among both the Sinhalese and ethnic minority communities in Sri Lanka. Many hoped it signified a new and cleaner

JONATHAN GOODHAND is a professor of conflict and development studies at SOAS, University of London. OLIVER WALTON is a lecturer in international development at the University of Bath. politics that would root out corruption and nepotism associated with the old regime. Others saw it as heralding an ambitious project of democratization, state reform, and transitional justice, aimed at bringing about a just and inclusive settlement to the "national question" of how best to ensure minority rights and political representation. And there were some who saw yahapalanaya as a necessary antidote to the economic populism and growing national debt associated with the previous government.

Sirisena's key campaign pledges included abolishing the executive presidency and reforming the electoral system. He also promised a reorientation of Sri Lanka's international relations, reengaging with Western countries to reduce the heavy reliance on China that had been established under the previous government, as well as a renewed commitment to human rights and transitional justice, though these issues were not explicitly part of his platform. This ambitious reformist agenda-mirroring a previous Norwegian-backed experiment in liberal peace building in its assumption that "all good things come together"-generated high expectations and initial enthusiasm, both domestically and in the West.

The National Unity government, capitalizing on this widespread support, soon began to follow through on its election promises. The nineteenth amendment to the constitution was ratified in April 2015, restoring key checks and balances on the president that had been removed by Rajapaksa. Its unanimous passage in Parliament reinforced the sense that the new government represented a different, more consensual way of doing politics, founded on the close cooperation of two mainstream parties that had been traditional rivals.

The coalition added to its already ambitious agenda by campaigning in the August 2015 parlia- 
mentary elections for a new charter of fundamental rights and the maximum possible devolution of power within a unitary state. The replacement of pro-Rajapaksa military governors in the north and east with civilian officials also raised hopes that this would be a first step in the demilitarization of the war-affected regions.

In the area of transitional justice, the new government cosponsored an October 2015 United Nations Human Rights Council (UNHRC) resolution promoting reconciliation, human rights, and accountability in Sri Lanka. This was seen as a significant shift from the previous regime, and evidence that the National Unity government had taken ownership of transitional justice, while also acknowledging that there was a role for international actors to play in a hybrid court-as recommended by a report issued in 2011 by the UN Secretary-General's Panel of Experts on Accountability in Sri Lanka. Rajapaksa, by contrast, had strongly resisted any international interference on questions of justice and accountability.

An investigation by the UN Office of the High Commissioner for Human Rights had found "horrific levels of violations and abuse" in Sri Lanka between 2002 and 2011. The Rajapaksa government's response to international and Tamil diaspora pressure had been to create a Lessons Learned and Reconciliation Commission, which critics saw as designed to play for time and evade questions of accountability. Indeed, only 19 of 189 recommendations made by the commission were fully implemented. The official discourse stressed reconciliation rather than accountability, and development rather dwelling on the past, while at the same time celebrating and memorializing the sacrifices made by patriotic war heroes to defeat the LTTE.

That seemed to change when the new government took power. Under the leadership of the new foreign minister, Mangala Samaraweera, there appeared to be some momentum behind the push for transitional justice. South African officials who had been involved with the postapartheid Truth and Reconciliation Commission were brought in to lend their expertise. The new government developed a strategy with four key strands: a truth commission; reparations; an Office for Missing Persons; and most controversially, an independent special court for war crimes, with the participation of foreign judges.
Steps were taken to put this strategy into action on a number of fronts. A Secretariat for Coordination of Conciliation Mechanisms was established, and legislation was passed to establish the Office for Missing Persons. A Consultation Task Force widely canvassed civil society about these measures and produced a final report in February 2017.

Consequently, election promises did yield real reforms by the new government in some areas. However, over time, it became evident that these efforts were meeting strong resistance, both within and outside the coalition. Increasingly the "new politics" began to look very similar to the old politics of patronage, horse trading, and compromise. This has led to growing public dissatisfaction, opening up new space for the old guard and its nationalist support base to mobilize.

\section{CONTINUITIES AND CONSTRAINTS}

For a government whose legitimacy rested on the perception that it represented a clean break with the past, and on its promise to clean up politics by pushing through an ambitious reform agenda, there was always the danger of a large gap between rhetoric and reality. The National Unity government is composed of a diverse coalition whose main common interest was defeating Rajapaksa. While inclusivity was the key to winning elections, it did not provide a strong foundation for decisive and reform-minded government. Siresena and Prime Minister Ranil Wickremesinghe came from very different political and social backgrounds. As a result, two distinct centers of power quickly emerged within the regime.

The 2015 elections were less transformative than they first appeared, and the continuities between the "old" and the "new" orders have become more apparent over time. The coalition contained many defectors from Rajapaksa's faction, whose loyalties could not be assured. The shadow of the old regime, which quickly materialized in the form of a Joint Opposition alliance in Parliament, limits Siresena's room for maneuver and increases the political distance between him and the prime minister. Whereas Wickremesinghe is comfortable with neoliberal economic policies and international calls for transitional justice, such policies are anathema to Sirisena's Sinhalese support base. 
The other element of the old elite that has significant holding power and can therefore block reforms that threaten its interests is the military. The political and economic potency of the defense establishment was reinforced during the civil war and the final years of the Rajapaksa regime. Examining its role is central to the question of war crimes and accountability. That is one of the reasons why the president has resisted the idea of a hybrid court, which could potentially involve foreign judges convicting as war criminals figures seen by many Sri Lankans as war heroes.

The economic legacies of the Rajapaksa period have placed further constraints on the new government. While conflict-affected regions have experienced sustained and rapid economic growth since 2009, much of it was driven by infrastructure investment that added to the nation's foreign-debt load and forced the government to accept an IMF rescue package in 2016. Development at the geographical margins of the state has been fueled by flows of capital from abroad or from Colombo, often with the close involvement of key figures from the previous regime or the military.

These patterns of postwar development have created new collaborations among capital, elites, and ethnonationalist ideology. This leads to new forms of social conflict by undermining the security of lowincome groups across the country. Questions of postwar justice thus have an important economic dimension, which sometimes gets missed in international debates about war crimes and accountability.

Sirisena's electoral victory came overburdened with expectations that the new government could address the wide range of problems that had come to the fore under the previous regime. Early optimism about a "Colombo spring" has been replaced with a rather more pessimistic outlook, as the government's approach to a range of issues has grown increasingly hesitant. Some see a worrying reemergence of the anti-democratic tendencies that grew acute during Rajapaksa's period in office. The government has struck seemingly politically motivated compromises with the Rajapaksa camp over corruption and war crimes investigations.

There appears to have been a drift from reformism to political normalization, erasing the distinc- tion between this regime and the previous one. Unstable coalition politics are leading to inertia, delaying tactics, and dissimulation. These political dynamics at the center reverberate in complex ways with political demands and mobilization in the periphery.

\section{MAXIMAL DEMANDS}

In the north, the Tamil National Alliance (TNA) leadership faces a series of dilemmas about how to engage with the central government, heightened by pressures from its own constituency. Should it prioritize accountability for war crimes or constitutional reform? At the time of writing, the TNA appears to have prioritized the latter, though this may change as the government's commitment to revising the constitution wavers.

Tamil leaders have sought to balance nationalist demands for autonomy and a more pragmatic engagement with the government to gain access to economic resources and patronage. In both respects they are being challenged by a resurgent Tamil nationalist movement led by rival parties such as the Tamil National People's Front, diaspora groups, and new political formations including the Tamil People's Council, which have pressed for a more maximalist position that aims to simultaneously end continued militarization of the north and address war crimes and the need for a federal solution to the national question.

The military's reluctance to return land to civilians continues to be a central issue impinging on public trust in the government in the north and east. Although the government made a commitment to reviewing high-security zones controlled by the military and prioritizing the return of internally displaced persons by cosponsoring the October 2015 UNHRC resolution, progress has been slow. In early 2017 , government inaction prompted outspoken criticism from the TNA leadership and a series of sustained public protests both in the north and in Colombo.

In the east, the leadership of the Sri Lanka Muslim Congress is being confronted by a more assertive regional identity movement called "the Rise of the East." In the south, anxieties over constitutional reform and transitional justice have been heightened by maximalist demands from the Tamil population: talk of federalism in the north fuels 
a narrative among Sinhalese nationalists of the necessity of protecting the unitary state.

Hambantota, an economically marginalized district in the deep south, symbolizes wider shifts in Sri Lanka's political relations. Under the Rajapaksa government, efforts to establish a new development hub in the district signaled both a rebalancing of economic and political power away from the center and an external strategy of forging closer ties with China. However, the current government's plans to establish a new industrial zone were heavily opposed by the Joint Opposition on the grounds that the scheme provided a 99-year lease to Chinese companies to develop the Hambantota port. Local politicians loyal to Rajapaksa were instrumental in mobilizing popular protests in December 2016 against the scheme and the Sirisena government. The protests reflected longstanding nationalist concerns about sovereignty and neocolonialism, albeit with the Chinese taking the place of Western colonizers.

These developments offer important clues as to the wider direction of the yahapalanaya coalition. Although the government is a coalition of two parties representing the Sinhalese majority, the success of its postwar package hinges on support from minority parties and constituencies at the margins.

\section{VICTORS' PEACE}

Meanwhile, a strong external constituency is pressing for the application of international models of postwar justice and accountability in Sri Lanka. But as these processes hit the ground, they become entangled in, and interact with, the complex domestic political landscape.

There is an increasingly sophisticated set of legal frameworks, institutions, and practices related to transitional justice in postwar contexts. The majority of cases deal with wars that ended with a negotiated settlement rather than a military victory. Sri Lanka poses particular challenges given the military defeat of the LTTE and the political capital gained by the victors. Historically, there are very few cases where the victors have voluntarily submitted themselves to a transitional justice process. In contexts where elites from the old regime retain significant power, there has been a tendency for "softer" forms of justice that focus on truthtelling and reconciliation instead of criminal accountability and punishment.

Transitional justice and peace-building processes provide opportunities for both the government and its critics to speak to and mobilize particular audiences, sometimes sending contrasting messages in different voices to different groups. Some of the government's measures on reconciliation, such as allowing the national anthem to be sung in Tamil, have sent reassuring signals to international observers. But on more contentious issues relating to accountability and justice, the government has been forced to yield to stronger pressure from the military and the Joint Opposition, which is quick to mobilize against perceived threats to Sri Lankan sovereignty.

Transitional justice involves difficult trade-offs. The assumption that all good things come together and that state reform, democratization, and transitional justice are mutually reinforcing ignores the complex and messy compromises required to make them happen. Morality tales about victims and perpetrators, the innocent and guilty, simplify the moral ambiguities and political complexities of how most societies have sought to build peace and come to terms with the past.

Since Sri Lanka gained independence from British rule in 1948, there have been repeated incidents of collective violence and atrocities, but few cases where the perpetrators have been brought to justice. Time provides a space for societal healing and compromise. But it also provides tactical opportunities for partisan actors. The Sirisena government's faltering progress on transitional justice illustrates how strategies of delay can allow compromises and tensions to be papered over and managed. For example, the government fulfilled one of its commitments to the UN Human Rights Council in August 2016 by rapidly pushing through legislation to establish an Office of Missing Persons. But at the time of writing, the law had still not been put into effect.

\section{LIMITED APPETITE}

There is a long-standing debate in Sri Lankan politics about whether to prioritize political stability and economic growth, or instead to emphasize the rule of law and political reform. A high level of path dependency may be present, with the legacy of past failures to reform (during the peace talks of 1994 and 2002-3) shaping public expectations and limiting political elites' room for maneuver at both the center and the margins. The defeat of Rajapaksa and the emergence of a national unity government committed to reform appeared to present an opportunity for pushing forward an ambitious transitional-justice agenda. Yet in practice the government has been heavily constrained by a set of 
compromises or tensions that have hampered its capacity to implement a coherent agenda.

From the outset, Sirisena had to stave off attacks from his own SLFP members of parliament, many of whom remain loyal to Rajapaksa. The former president has acted as the figurehead for the Joint Opposition, and has been vocal in his objections to many of the government's policies. The looming threat of an SLFP split has limited the president's appetite for backing bold reforms or challenging the military establishment. Furthermore, the president and prime minister have different priorities regarding state reform and accountability. Sirisena has publicly contradicted Wickremesinghe at times by denying the need for international involvement in a justice mechanism. These tensions are also linked to the differing expectations of domestic and international audiences.

The government has prioritized constitutional reform over measures to address postwar justice and accountability. But this approach is in tension with international mechanisms such as the UNHRC and the European Union's preferential tariff scheme, the Generalized System of Preferences, both of which set out specific targets for tackling issues relating to human rights, justice, and accountability. Transitional justice has become a bargaining chip in a high-stakes game: if the Tamil parties do not push too hard on war crimes, then the government may promise constitutional reforms in return. The proponents of transitional justice, however, argue that it is inseparable from constitutional reforms, since there is a need to address the governance structures that perpetuate injustice in the south as well as the north and east.

Despite enthusiastic championing by the foreign minister, there is no politically powerful group claiming ownership over and advancing transitional justice. It did not feature in the presidential or parliamentary elections in 2015 and was not part of the government's electoral mandate. It has been largely driven by international concerns, though the government did assume leadership on the issue when it cosponsored the UNHRC resolution in October 2015.

The government's primary concerns are the economy, party politics, and constitutional reform. To a large extent, it has used transitional justice as a means of placating international opinion. Its ef- forts have been marked by slow progress, missed deadlines, and ad hoc initiatives to deflect pressure.

The establishment of a Consultation Task Force (CTF), which involved widespread public discussion leading to the release of a report in January 2017, was a potentially significant step. The report emphasized the need for more proactive public communication on the government's transitional justice and reform efforts. It supported the participation of foreign judges in war crimes courts, in line with the October 2015 UNHRC resolution. The consultation process was welcomed by international observers and was seen as a valuable dialogue that included affected communities.

However, the CTF has been widely dismissed by nationalist critics as an elitist vehicle for Colombo-based nongovernmental organizations. Nationalist forces both outside and inside the government have used the CTF and other aspects of the transitional-justice process to legitimize themselves in the eyes of their supporters by playing on long-standing fears about foreign interference and the violation of state sovereignty. The president himself has dabbled in this rhetoric at times, as when he stated in March 2017 that he was not "ready to govern the country on NGO opinions."

In addressing issues of transitional justice, the government is bound by a variety of domestic and international timetables that often overlap and impinge on each other, causing tensions and contradictions. On the one hand, it is responding to domestic political pressures to hold local elections and a constitutional referendum, and to public opinion in the Sinhalese-majority south, which the government regards as largely hostile to robust action on transitional justice. On the other hand, the government is forced to react to the externally imposed timetables of the UNHRC and the EU, which call for more concrete and rapid progress in certain key areas.

\section{PLAYING FOR TIME}

The constraints binding the yahapalaynaya government have led to increasingly hesitant policy making. This faltering approach can be observed across most policy areas, with setbacks and reversals on key decisions regarding the economy and anticorruption efforts. But delays have been 
most evident with respect to constitutional reform and justice. Despite a wide-ranging set of public consultations on reform and transitional justice, and more than 50 meetings held by a parliamentary steering committee planning a Constitutional Assembly, it has not yet produced the draft report promised for December 2016. No settled positions have emerged on key issues pertaining to devolution, the electoral system, or abolition of the executive presidency.

The government has failed to communicate effectively to the public and as a result has ceded control of the political agenda to the Joint Opposition. Declining public confidence in the government's ability to deal decisively with issues relating to corruption, the economy, and state reform is acting as a further barrier to progress. As the government's popularity dwindles, its lack of confidence makes it hold off on calling local elections or a constitutional referendum.

At the time of writing, the government's efforts to implement the UNHRC resolution it cosponsored are under scrutiny in Geneva. The UNHRC's latest report, issued in March 2017, was highly critical of the government, calling its progress "worryingly slow" and stating that "the structures set up and measures taken until now have been inadequate," lacking "coordination and a sense of urgency."

Nevertheless, there is a widespread expectation that the government will be given more time to act on its commitments. Support for an extension has come from leading members of the TNA, includ- ing M.A. Sumanthiran, who has argued that while establishing special courts may take time, a new constitution can and should be concluded more quickly, alongside more concerted efforts to address disappearances and demands for the return of land. While it seems likely that the government will continue the delicate work of balancing the contrasting priorities and expectations of international and domestic audiences, perhaps the more critical challenge it faces is to establish a common agenda on state reform and transitional justice, and to communicate its goals more effectively to the public.

The window of opportunity appears to be rapidly closing. It was perhaps naive and overly optimistic to believe that regime change was the answer to a problem that has much deeper structural roots. The context is shaped by the legacies of war, a reform-resistant state, and a fractured political elite. The postwar direction pursued by the Rajapaksa regime did not emerge in a vacuum but rather drew on preexisting governing practices and ideologies, and was sustained through complex entanglements among state actors, elements of the business community, and nationalist forces. This does not mean that a solution to Sri Lanka's postwar conflicts - or at least a partial one-is impossible as a result of the current constellation of power. But it will take time, it has to be worked out by domestic players, and the justice that emerges will most likely depart from international standards of best practice. 